\title{
CURCUMIN-WHEY PROTEIN SOLID DISPERSION SYSTEM WITH IMPROVED SOLUBILITY AND CANCER CELL INHIBITORY EFFECT
}

\author{
LEVENTE RÁCZa, MARIA TOMOAIA-COTIȘELa , CSABA-PAL RÁCZa, \\ PAULA BULIERIS ${ }^{b}$, IOANA GROSU ${ }^{b}$, SEBASTIAN PORAV ${ }^{b}$, \\ ALEXANDRA CIORITT Â ${ }^{b}$, XENIA FILIP ${ }^{b}$, FLAVIA MARTIN ${ }^{b}$, \\ GEORGETA SERBAN ${ }^{c}$, IRINA KACSÓ ${ }^{b, *}$
}

\begin{abstract}
The solid dispersion system containing a high amount of the natural compound curcumin was prepared with whey protein concentrate by spray-drying method in 5:1 molar ratio. X-ray powder diffraction and DSC techniques show the formation of the solid dispersion system in amorphous state, and the presence of weak hydrogen bond type interactions between the components was established by FTIR analysis. SEM images show highly homogeneous donut-like spherical microparticles morphology for the system. The solubility of curcumin from the system was enhanced compared to practically insoluble raw curcumin, reaching a value of $70 \mu \mathrm{g} / \mathrm{mL}$ in aqueous buffer solution at $\mathrm{pH}=8$ similar with intestinal environment. The synthesized material had better effects against skin melanoma cells, compared to lung adenocarcinoma cells, but in both cases the effect was promising, and through further and more complex analyses the antitumoral potential of CUC-WPC_SD could be exploited.
\end{abstract}

Keywords: curcumin, whey protein concentrate, complexation, enhanced solubility, anticarcinogenic effect

\section{INTRODUCTION}

Curcumin (CUC) (1E,6E)-1,7-Bis(4-hydroxy-3-methoxyphenyl)-hepta1,6-diene-3,5-dione), with a diferuloylmethane structure was first isolated from rhizomes of Curcuma longa in 1815 as a yellow compound which exhibits

a Babeş-Bolyai University, Faculty of Chemistry and Chemical Engineering, 11 Arany Janos str., RO-400028, Cluj-Napoca, Romania

b National Institute of Research\&Development for Isotopic and Molecular Technologies, 67-103 Donath str., RO-400293 Cluj-Napoca, Romania

c University of Oradea, Faculty of Medicine and Pharmacy, 29 Nicolae Jiga str., RO-410028, Oradea, Romania

* Corresponding author: irina.kacso@itim-cj.ro 
biological and pharmaceutical activities. It has been used in traditional Chinese and Indian medicines for treatment of various diseases [1]. More and more research results show the efficiency of curcumin in the treatment of many medical conditions, as a result of the antioxidant, anti-inflammatory [2], antimicrobial [3], antiviral [4], neuroprotective [5] and, last but not least, anti-carcinogenic effect [6].

The chemical structure of CUC $\left(\mathrm{C}_{21} \mathrm{H}_{20} \mathrm{O}_{6}\right)$ (Figure 1) consists in two aryl rings containing o-methoxy phenolic $\mathrm{OH}$-groups symmetrically linked in conjugation through a $\beta$-diketone moiety which gives particular characteristics, such as intramolecular hydrogen atom transfer which determines the existence of keto-enol tautomerism, with important role in its physical-chemical properties [7]. The CUC molecule hydrophobicity is responsible for the very low solubility in aqueous medium, poor absorption, bioavailability and stability [8] that limit its therapeutic effectiveness. Thus, a large number of researches have been carried out and published in the last decade in attempt to improve the solubility and bioavailability of CUC, and to demonstrate its therapeutic effect in treatment of various diseases. Crystal engineering studies have led to the obtaining of polymorphs and co-crystals $[9,10]$ with higher solubility and dissolution rate compared to pure starting CUC. Inclusion complexes and different incorporation strategies of CUC into various carrier molecules, including but not limited to nanoparticles [11, 12], polymers [13], cyclodextrins [14], liposomes [11] or different proteins $[15,16]$ have been obtained and characterized, as well as micelles and solid dispersions [10, 11, 17], respectively.<smiles>COc1cc(/C=C/C(=O)/C=C(O)/C=C/C=C/c2ccc(/C=C/C(=O)CC(=O)/C=C/c3ccc(O)c(OC)c3)cc2OC)ccc1O</smiles>

Figure 1. Chemical structure of curcumin

One of the most used protein for increasing the solubility and bioavailability of CUC is whey protein. This protein possesses important nutritional and biological properties [18], antimicrobial, antiviral, anticarcinogenic activity and other metabolic features that have been associated with it [19]. It's being used in the whey protein concentrate (WPC) or isolate (WPI) form, that contains $65-90 \% \beta$-lactoglobulin [18]. In addition to the $\beta$-lactoglobulin main component the whey protein also contains a-lactalbumin, immunoglobulin, serum albumin, casein and other components. The amino acid sequence and three-dimensional structure confer to the $\beta$-lactoglobulin the ability to 
bind small hydrophobic ligands and therefore it can act as a specific transporter for them [20]. This ability is also supplemented by its antioxidant potential [21].

The solubility, stability and bioavailability improvement of CUC with whey protein or $\beta$-lactoglobulin was performed by different ways. CUC was loaded in WPI obtaining whey protein aggregates in emulsion [16] or whey protein hydrolysate in suspension [22]. Other studies reported the complexation of CUC and WPI in form of micro- or nano-encapsulates [23-25] or nanoemulsions [26], the $\beta$-lactoglobulin being also used for the same purpose [2729]. In addition, the biological activity of CUC, such as the antioxidant [16, 23, 30] and anticancer [25] effect, was enhanced, thus encouraging the use of these complexes in pharmaceutical, nutraceutical or food [16] applications.

Most studies on CUC with whey protein or $\beta$-lactoglobulin complexation have been performed on 1:1 molar ratio [16, 27, 28, 31]. Few studies investigate the complexation using an excess of CUC, as in the case of nano-encapsulates [25].

The aim of our study is to prepare an enhanced solubility solid-state curcumin-whey protein concentrate dispersion system (CUC-WPC_SD) with high amount of curcumin content by spray drying (SD) method, whose efficiency is proved by the literature data $[15,24,30]$.

Curcumin - whey protein solid dispersion systems were prepared in different molar ratios, from 1:1 to $20: 1$, whose preliminary analysis regarding the solubility and stability showed that 5:1 stoichiometry (CUC-WPC_SD) is the optimal formula for the proposed purpose. The identification of the system was highlighted by X-ray powder diffraction (XRPD), Fourier transform infrared spectroscopy (FTIR) and differential scanning calorimetry (DSC). The morphological characterization was realized by scanning electron microscopy (SEM) and the dissolution by UV spectrophotometry. The in vitro cytostatic activity was tested on several cancer cell types.

\section{RESULTS AND DISCUSSION}

\section{CUC-WPC_SD complex characterization}

$X$-ray powder diffraction (XRPD)

In order to prove the solid disperse system CUC-WPC_SD obtained by CUC incorporation into WPC, in the optimized molar ratio $5: 1$, first it was analyzed by XRPD. 
L. RÁCZ, M. TOMOAIA-COTIȘEL, C.P. RÁCZ, P. BULIERIS, I. GROSU, S. PORAV, A.CIORITȚĂ, X. FILIP, F. MARTIN, G. SERBAN, I. KACSÓ

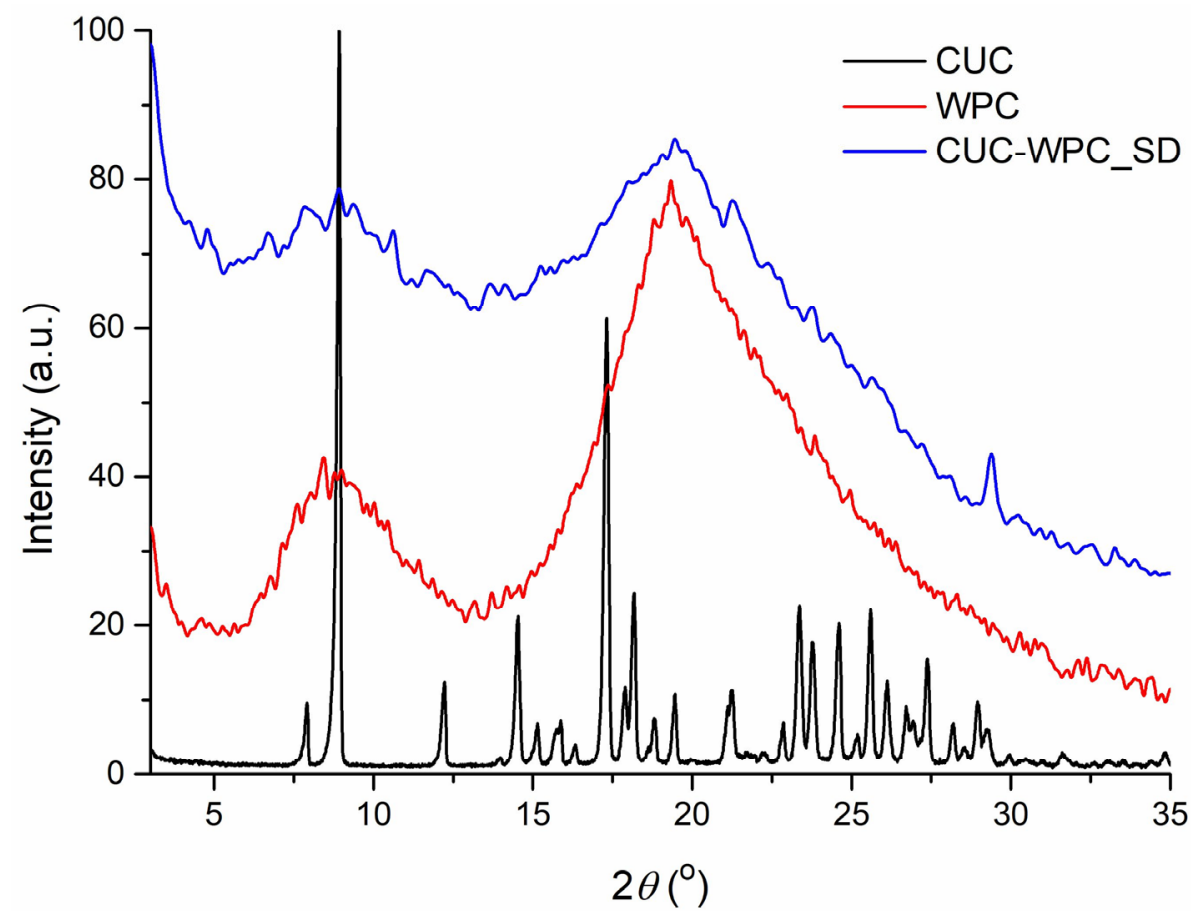

Figure 2. The compared PXRD patterns of CUC, WPC and CUC-WPC_SD

The diffractograms of raw CUC and WPC were compared with CUC-WPC_SD one (Figure 2). It was observed that the analyzed sample is in an amorphous state, without being able to distinguish the characteristic diffraction lines of CUC, which suggests its loading in WPC and a homogeneous dispersion system formation.

\section{Differential scanning calorimetry (DSC)}

The DSC curve of CUC (Figure 3) shows a sharp endothermic melting signal with $\mathrm{T}_{\text {on }}=172.6^{\circ} \mathrm{C}, \mathrm{T}_{\text {peak }}=177.8^{\circ} \mathrm{C}$ and $\Delta \mathrm{H}=-194.6 \mathrm{~J} \cdot \mathrm{g}^{-1}$, and presents thermal stability up to $200^{\circ} \mathrm{C}$. The DSC trace of WPC shows an amorphous material, without significant thermal events, observing only one broad endothermic signal between $40-100^{\circ} \mathrm{C}$, corresponding to the unbounded water elimination. 


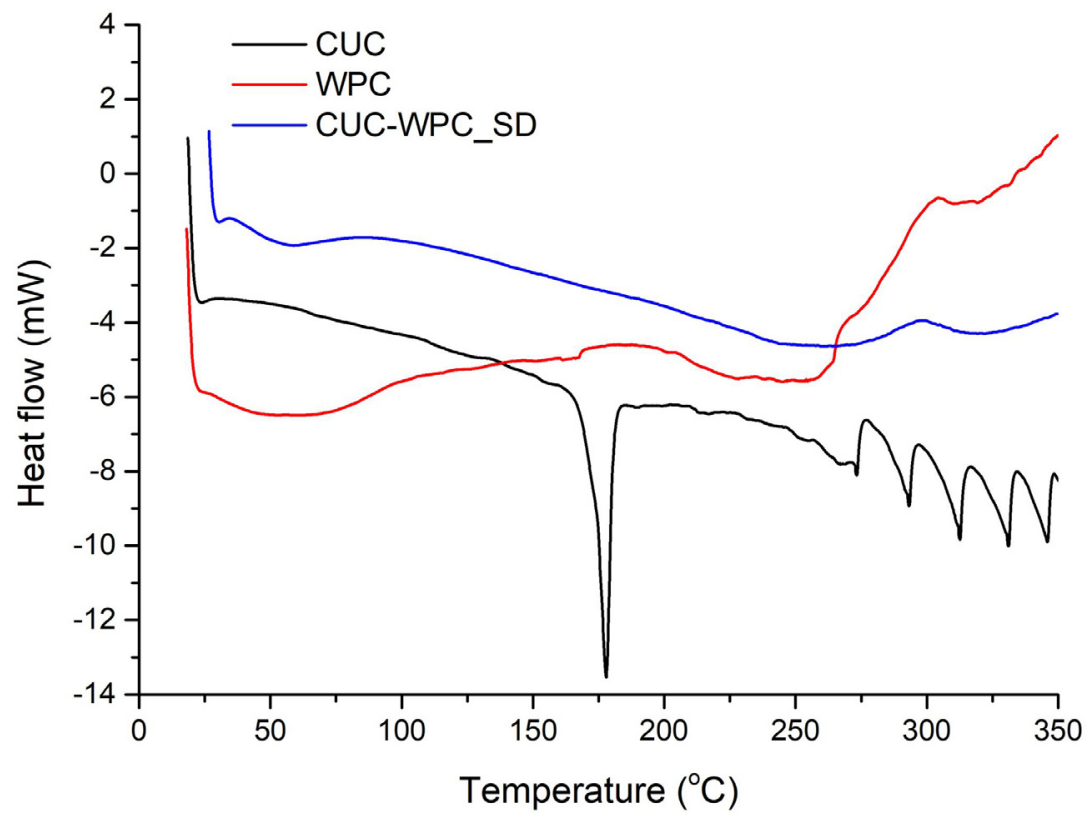

Figure 3. The compared DSC curves of CUC, WPC and CUC-WPC_SD

Analyzing the DSC curve of CUC-WPC_SD one can observe one low intensity broad endotherm signal between 40 and $90^{\circ} \mathrm{C}$ due to the residual unbounded water elimination, but the melting signal of CUC does not appears, which indicates that the loading of curcumin in whey protein in 5:1 stoichiometric ratio occurs.

\section{Fourier transform infrared spectroscopy (FTIR)}

The changes in the position, intensity or width of the characteristic vibrational bands of curcumin and whey protein on the CUC-WPC_SD system FTIR spectrum could be explained by the transformations and interactions that occur during the incorporation process. On the CUC-WPC_SD dispersion system FTIR spectrum one can identify the most important absorption bands of CUC [32] and those of WPC with certain modifications (Figure 4).

Regarding the characteristic vibrational bands of CUC in the spectrum of CUC-WPC_SD sample the following changes appear: the $\mathrm{C}=\mathrm{O}$ stretching from $1627 \mathrm{~cm}^{-1}$ and the aromatic $C=C$ stretching from $1602 \mathrm{~cm}^{-1}$ disappear; the aromatic ring bending vibration from $1509 \mathrm{~cm}^{-1}$ shift to $1516 \mathrm{~cm}^{-1}$; the $\mathrm{CH}_{2}$ bending from $1429 \mathrm{~cm}^{-1}$ and the $\mathrm{C}-\mathrm{O}$ stretching from $1207 \mathrm{~cm}^{-1}$ shift to $1431 \mathrm{~cm}^{-1}$ and $1210 \mathrm{~cm}^{-1}$, respectively and both appear as a shoulder; the C-O stretching from $1154 \mathrm{~cm}^{-1}$ and $1121 \mathrm{~cm}^{-1}$ shift to $1163 \mathrm{~cm}^{-1}$ and 
L. RÁCZ, M. TOMOAIA-COTIȘEL, C.P. RÁCZ, P. BULIERIS, I. GROSU, S. PORAV, A.CIORITTिĂ, X. FILIP, F. MARTIN, G. SERBAN, I. KACSÓ

$1127 \mathrm{~cm}^{-1}$, respectively; the $\mathrm{C}-\mathrm{OH}$ stretching from $1028 \mathrm{~cm}^{-1}$ and the benzoate trans- $\mathrm{CH}$ vibration from $963 \mathrm{~cm}^{-1}$ shift to $1034 \mathrm{~cm}^{-1}$ and at $970 \mathrm{~cm}^{-1}$, respectively.
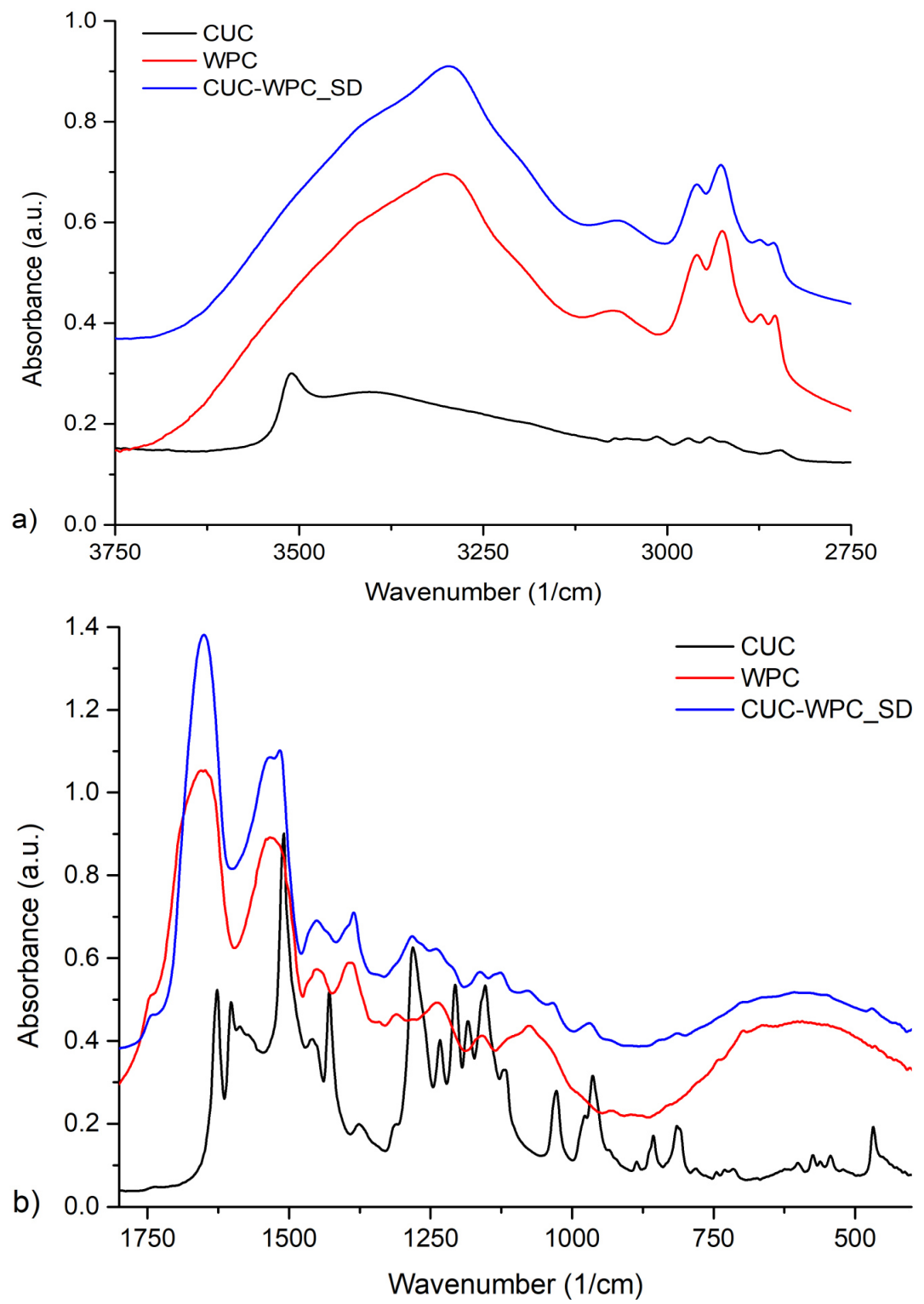

Figure 4. The compared FTIR spectra of CUC, WPC and CUC-WPC_SD, spectral domain a) $3750-2750 \mathrm{~cm}^{-1}$ and b) $1800-400 \mathrm{~cm}^{-1}$ 
As a result of the loading with CUC, the characteristic vibrational bands of WPC have undergone the following changes: the shoulder at $1694 \mathrm{~cm}^{-1}$, assigned to protein aggregates [33], no longer appears; the amide I band, due to the stretching vibrations of $\mathrm{C}=\mathrm{O}$ in the peptide bonds [34] from $1657 \mathrm{~cm}^{-1}$ shift to $1650 \mathrm{~cm}^{-1}$ and becomes narrower; the vibration bands from 1533 and $1392 \mathrm{~cm}^{-1}$ were shifted to $1517 \mathrm{~cm}^{-1}$ and to $1386 \mathrm{~cm}^{-1}$ respectively; the low intensity vibration band from $1309 \mathrm{~cm}^{-1}$ was shifted and appears as a shoulder at $1314 \mathrm{~cm}^{-1}$, the medium intensities sharp vibration bands from 1237 and $1158 \mathrm{~cm}^{-1}$ shifts to 1240 and $1162 \mathrm{~cm}^{-1}$, respectively. The outlined changes of some vibration bands, especially those characteristics of the $\mathrm{OH}$ and $\mathrm{COOH}$ groups, suggest the existence of some weak hydrogen bond- and electrostatic-type interactions between the two components of the CUC-WPC_SD dispersion system.

\section{Scanning electron microscopy (SEM)}

Morphological analysis of CUC-WPC_SD sample, presented in Figure 5, revealed an amorphous state without any crystalline features. In terms of shape, the sample is highly homogeneous, the particles adopting a donut-like form.

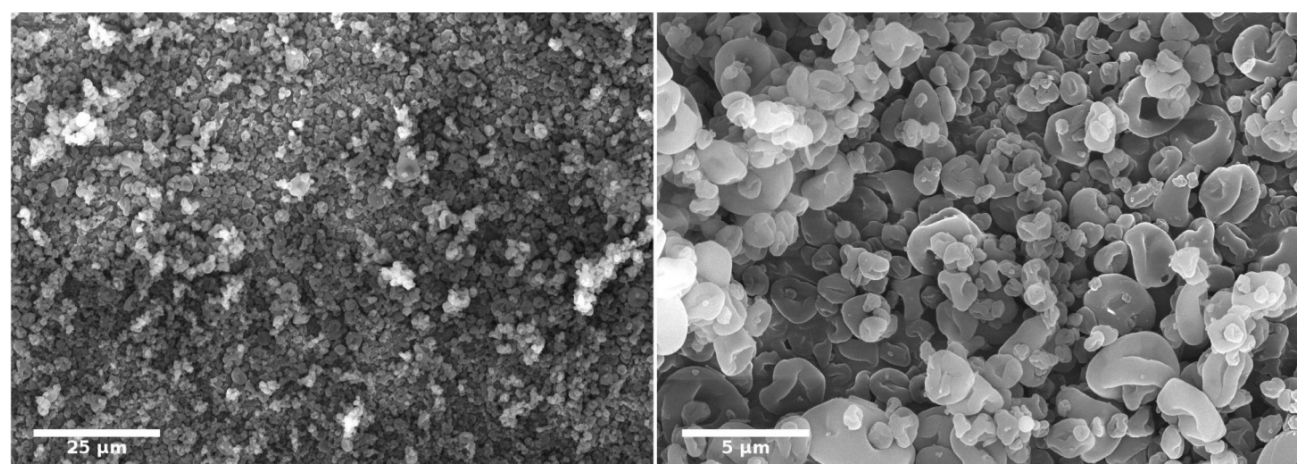

Figure 5. SEM images of the particle size distribution in the CUC-WPC_SD sample

The particle size distribution showed a relatively large interval, varying between $0.17 \mu \mathrm{m}$ to $4.9 \mu \mathrm{m}$ and having a mean size of $1.5 \mu \mathrm{m}$. Despite the wide range, the size distribution follows a Gaussian curve (Figure 6). 
L. RÁCZ, M. TOMOAIA-COTIȘEL, C.P. RÁCZ, P. BULIERIS, I. GROSU, S. PORAV, A.CIORITTĂ, X. FILIP, F. MARTIN, G. SERBAN, I. KACSÓ

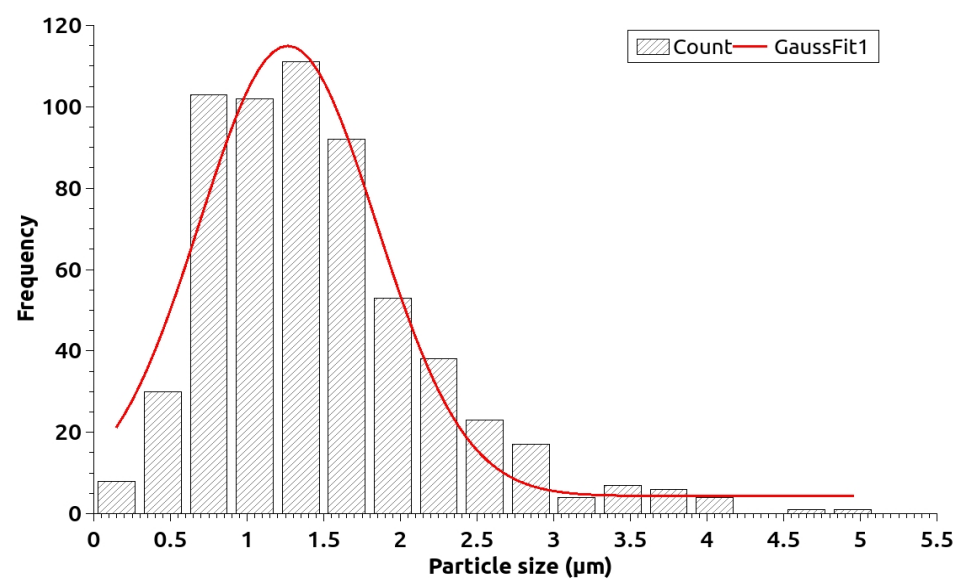

Figure 6. The Gaussian curve of particle size distribution

\section{Powder dissolution measurements}

The solid dispersion system CUC-WPC_SD was subjected to the dissolution experiment in deionized water and in aqueous buffer at 1.8 and 8 physiologically $\mathrm{pH}$ values, respectively. The curcumin concentration in the CUC-WPC_SD solution was monitored over time, by recording the absorption intensity for a period of $160 \mathrm{~min}$ (Figure 7). On figure 7 the dissolution profile of raw curcumin, practically insoluble in water, was also represented.

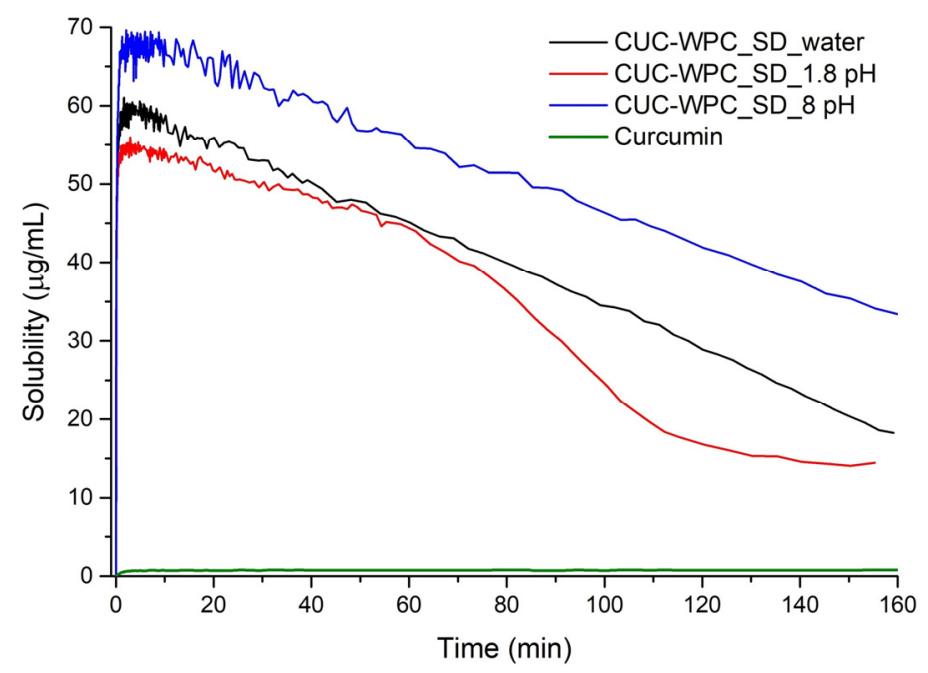

Figure 7. Variation of curcumin concentration in aqueous solutions of CUCWPC_SD compared with the solubility of pure curcumin 
The dissolution profile of CUC contained in the CUC-WPC_SD system in water (concentration of CUC $(\mu \mathrm{g} / \mathrm{mL})$ as a function of time $(\mathrm{min})$ ), shows the maximum concentration of $\sim 60 \mu \mathrm{g} / \mathrm{mL}$ almost instantaneously, after which a linear decreasing trend in the curcumin concentration in solution is manifested, due to CUC precipitation over time.

In aqueous buffer with $\mathrm{pH}=1.8$ (similar with gastric liquid) the maximum concentration of CUC reaches a value of $\sim 55 \mu \mathrm{g} / \mathrm{mL}$. In the first 60 minutes of the dissolution experiment a linear decreasing tendency to a value of $45 \mu \mathrm{g} / \mathrm{mL}$ was observed, after which there is a sudden decrease of the amount of dissolved curcumin.

The dissolution profile in buffer with $\mathrm{pH}=8$ (similar to the $\mathrm{pH}$ of the intestinal environment) shows instantaneously dissolution of CUC to the maximum concentration of $\sim 70 \mu \mathrm{g} / \mathrm{mL}$, after which there is a linear decreasing tendency due to CUC precipitation. After $160 \mathrm{~min}$, the final CUC concentration was $\sim 35 \mu \mathrm{g} / \mathrm{mL}$.

No decomposition of curcumin at all the $\mathrm{pH}$ values in the performed dissolution tests was observed.

\section{Cytotoxicity tests}

The obtained CUC-WPC_SD dispersion system was tested in vitro against skin melanoma (A375) and lung adenocarcinoma (A549) cells. The A375 cells were affected to a higher extent compared to A549 cells $\left(p<0.0001\right.$, Figure 8a), aspect indicated also by the $\mathrm{IC}_{50}$ concentration. The results showed that CUC-WPC_SD has an $I_{50}$ value of $45.5 \mu \mathrm{g} / \mathrm{mL}$ against A375 cells and $203.6 \mu \mathrm{g} / \mathrm{mL}$ against A549. Compared to the untreated control, A375 cells were significantly more affected $(p<0.0001)$ starting with the concentration of $30 \mu \mathrm{g} / \mathrm{mL}$, whereas for A549 the concentrations of $200 \mu \mathrm{g} / \mathrm{mL}$ and $300 \mu \mathrm{g} / \mathrm{mL}$, were the most effective. However, at the lowest concentration tested $(10 \mu \mathrm{g} / \mathrm{mL})$, both cell lines had a proliferative response, with registered values above those of the untreated controls (119\% for A549, and $120 \%$ for A375, respectively).

The LDH values calculated herein, show no significant difference between the two cell lines (Figure $8 \mathrm{~b}$ ). Compared to the cells treated with Tween 20, no necrosis was observed, however, the negative values registered could indicate a membrane blockage [35].

A direct dose dependent reaction was observed in A375 cells that registered high NO values at concentrations above $30 \mu \mathrm{g} / \mathrm{mL}$. The results are consistent with the observed effects on the MTT assay. A dose dependent reaction was observed for A549 cells as well, however the trend was more chaotic (Figure 8c), compared to the skin melanoma cells. Nevertheless, the highest value registered for the NO concentration, was associated with the lowest value registered for the MTT assay, in both cell types. 
L. RÁCZ, M. TOMOAIA-COTIȘEL, C.P. RÁCZ, P. BULIERIS, I. GROSU, S. PORAV, A.CIORIṬĂ, X. FILIP, F. MARTIN, G. SERBAN, I. KACSÓ
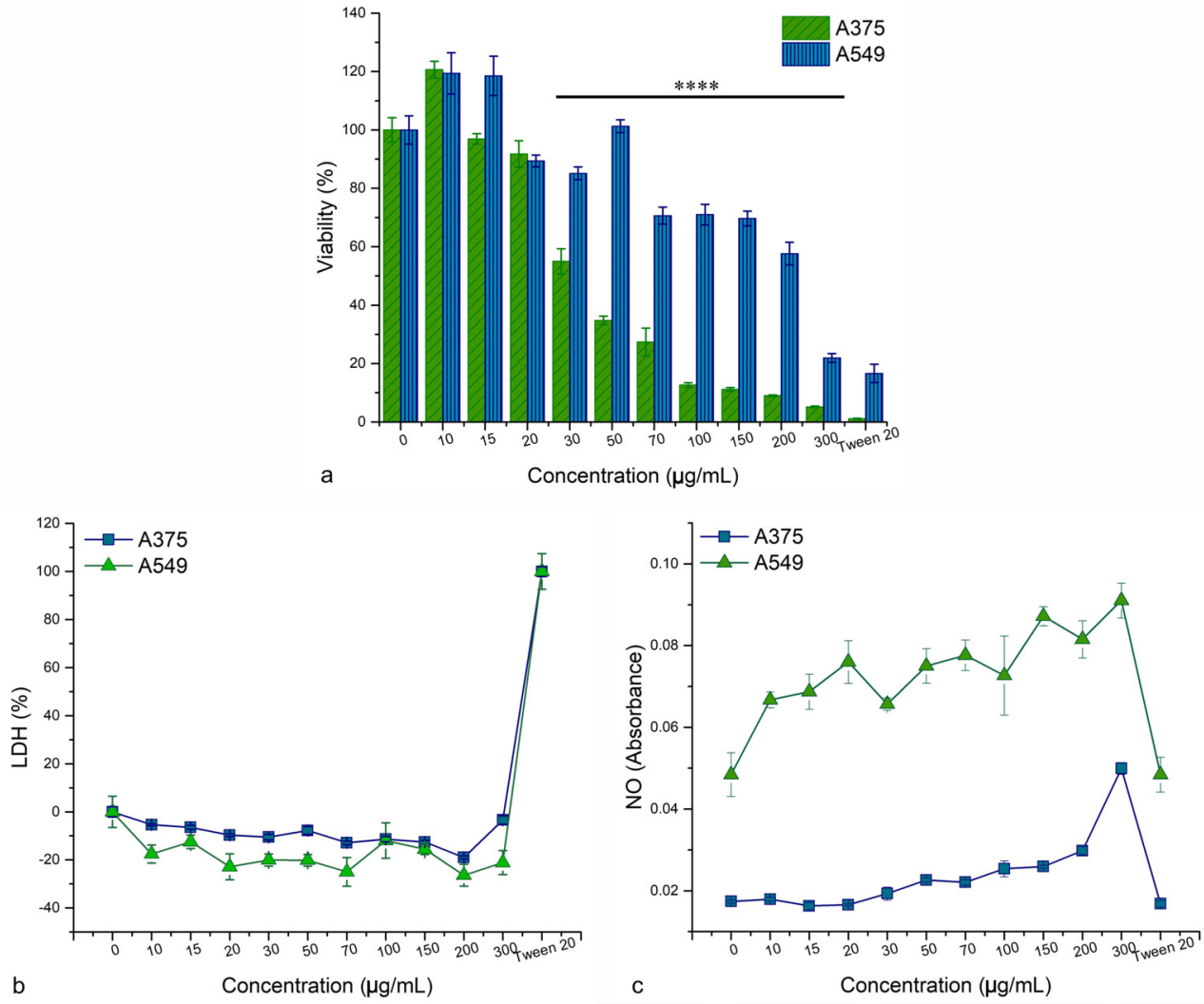

Figure 8. Cytotoxicity assays performed on A375 and A549 cells, treated with CUC-WPC_SD. a) MTT assay showing the extend of damages induced in the cells' viability in $24 \mathrm{~h}$. b) LDH assay showing the amount of LDH released in the culture media of the cells treated with the drug for $24 \mathrm{~h}$. c) $\mathrm{NO}$ assay revealing the amount of nitric oxide released in the culture media of the treated cells.

The NO concentration has a controversial background, as it can indicate both apoptotic and proliferative effects. This means that at low concentrations detected, the apoptosis could be rescued, but tumor inhibition through apoptosis has also been reported for the same scenario [36]. Therefore, the Griess assay is associated with other biochemical analyses such as LDH and MTT, considered for this study, to be able to correlate the events observed. Herein, for both A375 and A549 cells a moderate negative correlation $(r=-0.7)$ was observed between the viability and NO assay test results. This indicates that at high concentrations (starting with $30 \mu \mathrm{g} / \mathrm{mL}$ drug concentration), the inhibition of the cancer cells tested was achieved through apoptosis, rather than necrosis. 
Similar results were obtained in other previous studies. By testing nano-encapsulated curcumin with whey protein against different cancer cell lines (colon, prostate, and pancreatic cancers), a better inhibitory capacity was observed compared to pure curcumin [25]. When polyethylene glycol was used to enhance the solubility of curcumin, a strong inhibitory capacity against multiple pancreatic cancer cells was obtained [37]. The $I C_{50}$ values of curcumin alone ranged from 7 to $18 \mu \mathrm{M}$, whereas for the PEG-loaded curcumin, the values decreased to more than half. Also, the incorporated curcumin in catanionic lipid nano-systems was tested for its effect against Lewis lung cancer, the $\mathrm{IC}_{50}$ value of curcumin nano-systems $(20.2 \mu \mathrm{M})$ was almost half of that of curcumin used alone $(39.7 \mu \mathrm{M})$ [38].

\section{CONCLUSIONS}

The CUC-WPC_SD solid dispersion system was prepared by spraydrying in 5:1 molar ratio. Combining the XRPD, DSC, FTIR and SEM analysis results highlight the formation of the amorphous material whose components are joined by weak electrostatic interactions, being highly homogeneous, and adopting a donut-like spherical form.

The dissolution process of curcumin from this system shows a maximum solubility value of $70 \mu \mathrm{g} / \mathrm{mL}$ in aqueous buffer solution at $\mathrm{pH}=8$, similar of intestinal fluid, and the active component being stable in this environment.

The obtained dispersion system manifested better effects against skin melanoma cells, compared to lung adenocarcinoma cells, but in both cases the effect was promising, and through further and more complex analyses the antitumoral potential of CUC-WPC_SD could be exploited. The inhibition of skin melanoma cells (A375) is dose dependent in $24 \mathrm{~h}$. However, at low concentrations $(10 \mu \mathrm{g} / \mathrm{mL})$ the effect was proliferative, with values above the untreated control. The LDH release was constant at all tested concentrations. The nitric oxide (NO) concentration increased in a dose dependent manner, with values above the negative control (cells treated with Tween 20).

\section{EXPERIMENTAL SECTION}

\section{Materials}

All chemicals used for CUC-WPC_SD preparation and testing: curcumin, ethanol, propanol, DMEM F-12, L-glutamine, penicillin-streptomycin solution, Tris base, lithium lactate, NAD solution, sulfanilamide, formazan 
L. RÁCZ, M. TOMOAIA-COTIȘEL, C.P. RÁCZ, P. BULIERIS, I. GROSU, S. PORAV, A.CIORITṬĂ, X. FILIP, F. MARTIN, G. SERBAN, I. KACSÓ

salt, and $\mathrm{N}$-(1-naphthyl) ethylene-diamine were purchased from Sigma-Aldrich, Germany; the weight protein concentrate (WPC) was from Merck, Germany, and the fetal bovine serum from HyClone, Thermo Fisher Scientific, UK. All these chemicals were used without further purification. The cells used in cytotoxicity studies, A549 (ATCC CCL-185) and A375 (ATCC CRL-1619), were purchased from Lomianki, Poland.

\section{Preparation of CUC-WPC_SD solid dispersion system}

The solid starting compounds, CUC $\left(\mathrm{M}_{\mathrm{W}}=368.38 \mathrm{~g} / \mathrm{mol}\right)$ and WPC $\left(M_{W}=\sim 18400 \mathrm{~g} / \mathrm{mol}\right)$, were weighed for a molar ratio of CUC:WPC of $5: 1$ $(1: 10 \mathrm{w} / \mathrm{w})$. Curcumin was dissolved in ethanol and the WPC in distilled water. Before mixing the solutions, the WPC aqueous solution was filtered, the volume was corrected with distilled water for a concentration of $\leq 4 \%$ in ethanol. The obtained yellow, slightly milky solution was processed using a SF-1500LAB spray dryer, applying the following parameters: $T_{\text {in }}=165^{\circ} \mathrm{C}$ and $T_{\text {out }}=49^{\circ} \mathrm{C}$, ventilator frequency $58 \mathrm{~Hz}$, solution flow rate $5 \mathrm{~mL} / \mathrm{min}$. In the end a fine, homogeneous yellow-orange powder was obtained.

\section{$X$-ray powder diffraction (XRPD)}

Data collection was acquired with the DIFFRAC plus XRD Commander using a Brucker D8 Advance Diffractometer with the tube set at $40 \mathrm{kV}$ and $40 \mathrm{~mA}$, equipped with a germanium (1 111 ) monochromator, used to obtain

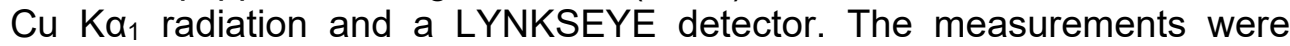
recorded in Bragg-Brentano geometries - variant in reflections- in $3-35^{\circ} 2 \theta$ range, employing a scan rate of $0.02 \%$.

\section{Differential scanning calorimetry (DSC)}

Thermal measurements were performed with a DSC-60 Shimadzu differential scanning calorimeter in standard aluminum crimped pans as sample holders and alumina as reference sample. Samples have been analyzed in the $20-350^{\circ} \mathrm{C}$ temperature range under dry nitrogen flow $\left(3.5 \mathrm{~L} \cdot \mathrm{h}^{-1}\right)$ with a $10^{\circ} \mathrm{C} \cdot \mathrm{min}^{-1}$ heating rate. For data collection and analysis, the Shimadzu TAWS60 and TA60 2.1 software were employed. The DSC calorimeter was calibrated with reference standards of zinc and indium.

\section{Fourier-Transform Infrared Spectroscopy (FTIR)}

FT-IR spectra were obtained using a JASCO 6100 FTIR spectrometer in the 4000 to $400 \mathrm{~cm}^{-1}$ spectral domain, with a resolution of $4 \mathrm{~cm}^{-1}$ by employing the $\mathrm{KBr}$ pellet technique. Each sample has been dispersed in 
about $300 \mathrm{mg}$ of anhydrous $\mathrm{KBr}$ and the resulting powder was ground in an agate mortar. The pellet was obtained by pressing the ground mixture into an evacuated die. The spectra were collected and analyzed with Jasco Spectra Manager v.2 software.

\section{Scanning electron microscopy (SEM)}

Samples provided for SEM analysis were prepared in the same fashion, briefly. The spray-dried samples were spread over the doublesided conductive tape $(12 \mathrm{~mm})$ fixed on aluminum stubs and coated with a $10 \mathrm{~nm}$ layer of gold. Image acquisition was conducted on a Hitachi SU8230 High Resolution Scanning Electron Microscope equipped with a cold field emission gun and a 80 X-Max system from Oxford Ins. for EDS analysis. For this analysis the microscope was operated at $30 \mathrm{kV}$ in high mag. mode. Approximately $85 \%$ of the carbon disk was scanned to give a realistic overview of the sample and only a few representative areas were captured.

\section{Powder Dissolution Experiments}

The absorbance values for curcumin and CUC-WPC_SD system in deionized water and buffer solutions were detected by a pION $\mu D I S S$ Profiler apparatus, consisting of an integrated diode array spectrophotometer connected to a fiber optic UV probe located directly in the reaction vessel and is able of measuring the concentration as a function of time without having to filter the solution. Measurement of dissolution kinetics and equilibrium solubility was carried out at $470 \mathrm{~nm}$, where the used protein has no absorption, and the concentration of curcumin was calculated by means of a standard curve. In a typical experiment, $10 \mathrm{~mL}$ of solvent (deionized water, $\mathrm{pH} 5.8$ or buffer solutions with $\mathrm{pH} 1.8$ and 8.0 ) was added to a flask containing $10 \mathrm{mg}$ of sample, and the resulting mixture was stirred at $25^{\circ} \mathrm{C}$ and $600 \mathrm{rpm}$. The dissolution experiment with 160 min monitoring time was carried out in triplicate. The calibration curve was performed at $470 \mathrm{~nm}$, a value at which WPC does not show an absorption signal, using a solution of curcumin in ethanol (Figure 9$)$. The linear equation $(y=0.0331 x+0.0149)$ derived from the calibration curve was used to calculate the amount of dissolved CUC during the dissolution process. 
L. RÁCZ, M. TOMOAIA-COTIȘEL, C.P. RÁCZ, P. BULIERIS, I. GROSU, S. PORAV, A.CIORITTĂ, X. FILIP, F. MARTIN, G. SERBAN, I. KACSÓ

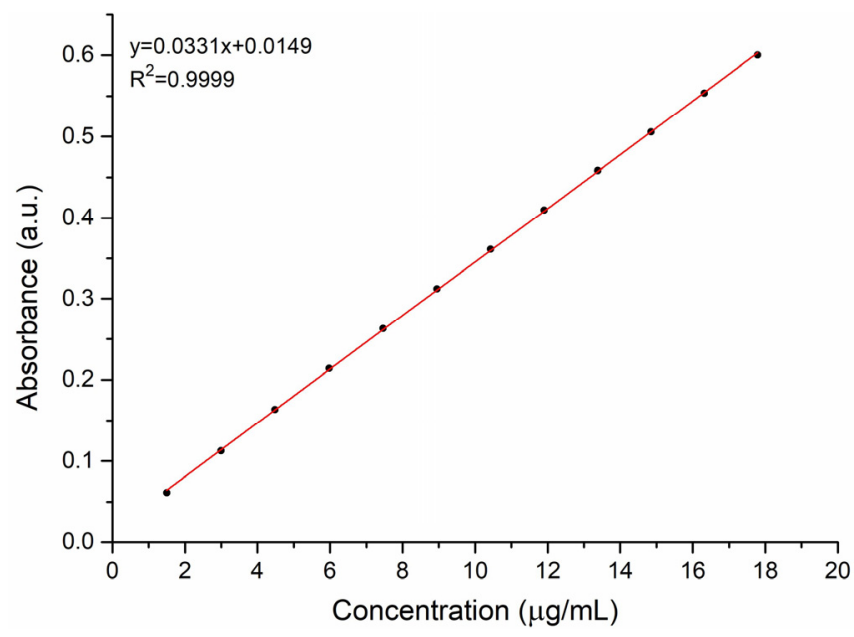

Figure 9. Calibration curve of curcumin concentration in ethanol

\section{Cytotoxicity experiments}

Cell culture. CUC-WPC_SD was tested in vitro against lung adenocarcinoma A549 (ATCC CCL-185) and skin melanoma A375 (ATCC CRL-1619) cells. A549 cells were maintained in DMEM F-12 media, supplemented with $10 \%$ fetal bovine serum, and A375 cells was kept in DMEM F-12 media supplemented with $10 \%$ fetal bovine serum, $1 \%$ L-glutamine and $1 \%$ penicillin-streptomycin solution. Both cell lines were grown in $25 \mathrm{~mL}$ flasks, at $37^{\circ} \mathrm{C}$ and $5 \% \mathrm{CO}_{2}$ in humified atmosphere.

Treatment. Three types of biochemical analyses were performed according to the ISO 10993-5 standard. Briefly, at an $80 \%$ confluence, the cells were transferred in 96 well plates and left for $24 \mathrm{~h}$ to attach. After this period, the treatment with CUC-WPC_SD was applied in increasing concentrations (10 $300 \mu \mathrm{g} / \mathrm{mL}$ ) for an additional $24 \mathrm{~h}$.

Cell viability was assessed through the MTT assay and the value at which $50 \%$ of the cells is affected $\left(\mathrm{IC}_{50}\right)$ was calculated. The media from the treated cells was analysed for lactate dehydrogenase release (LDH assay) and for nitric oxide production (NO Griess assay). The work flow was as follows: $150 \mu \mathrm{L}$ of $\mathrm{LDH}$ regent (Tris base $20 \mathrm{mM}$, lithium lactate, and NAD solution) was mixed with $50 \mu \mathrm{L}$ of media, and $100 \mu \mathrm{L}$ of NO regent (sulphanilamide and $\mathrm{N}$-1-napthylethylenediamine) was mixed with $50 \mu \mathrm{L}$ of media. The reagents were left with the media for $10 \mathrm{~min}$ in dark, at room temperature, after which the absorbances were read at $630 \mathrm{~nm}$ and $490 \mathrm{~nm}$ for LDH, and $548 \mathrm{~nm}$ for NO. 
The cells remaining in the wells were incubated for an additional $1.5 \mathrm{~h}$ with $100 \mu \mathrm{L}$ MTT solution. Forward, the formazan salt was dissolved with acidified propanol for $5 \mathrm{~min}$, and the absorbance was read at $630 \mathrm{~nm}$ and $550 \mathrm{~nm}$. The BioTek plate reader, coupled with Gen5 Software was used (Epoch, Germany), and each plate contained a positive untreated control, a negative control (cells treated with $2 \%$ Tween 20 ), and vehicle controls (media mixed with reagents and CUC-WPC_SD, without cells).

Statistical analyses. Each experiment had six replicates and the mean was calculated from at least three independent experiments. Oneway ANOVA and Students test were performed using the OriginPro 9.3 Software, and $P$ values of $\leq 0.05$ were considered significant.

\section{ACKNOWLEDGMENTS}

The authors acknowledge financial support from the Ministry of Research and Innovation- $\mathrm{MCl}$, Operational Program Competitiveness, POC Project 18/01.09.16, SMIS Code 105533.

\section{REFERENCES}

1. B. B. Aggarwal, Curcumin: the Indian solid gold, In The Molecular Targets and Therapeutic Uses of Curcumin in Health and Disease, B. B. Aggarwal, Y. J. Surh, S Shishodia, Springer, Boston, MA, 2007, Vol 595, Chapter 1, pp. 1-75

2. S. J. Hewlings, D. S. Kalman, Foods, 2017, 6(10), 92; doi:10.3390/foods 6100092

3. A. Adamczak, M. Ozarowski, T. M. Karpinski, Pharmaceuticals, 2020, 13(7), 153; doi:10.3390/ph13070153

4. D. C. Mathew, W.-L. Hsu, J. Funct. Foods, 2018, 40(692), 692-699

5. A. Askarizadeh, G. E. Barreto, N. C. Henney, M. Majeed, A. Sahebkar, Int. J. Pharm., 2020, 585, 119476; doi.org/10.1016/j.ijpharm.2020.119476 R

6. M. A. Tomeh, R. Hadianamrei, X. Zhao, Int. J. Mol. Sci., 2019, 20, 1033; doi:10.3390/ijms20051033

7. S. Mondal, S. Ghosh, S. P. Moulik, J. Photochem. Photobiol. B: Biol., 2016, 158, 212-218

8. M. L. A. D. Lestari, G. Indrayanto, Chapter three. Curcumin, In Profiles of Drug Substances, Excipients, and Related Methodology, First ed., H. Britain Ed., Academic Press, Elsevier Inc., 2014, Vol. 39, pp.113-204,

9. P. Sanphui, G. Bolla, Cryst. Growth Des., 2018, 18, 5690-5711

10. K. Suresh, A. Nangia, Cryst. Eng. Comm., 2018, 20, 3277-3296

11. Z. Liu, J. D. Smart, A. S. Pannala, J. Drug Deliv. Sci. Technol., 2020, 60, 102082; doi: 10.1016/j.jddst.2020.102082 R

12. K. Ahmed, Y. Li, D. J. McClements, H. Xiao, Food Chem., 2012, 132, 799-807 
L. RÁCZ, M. TOMOAIA-COTIȘEL, C.P. RÁCZ, P. BULIERIS, I. GROSU, S. PORAV, A.CIORITṬĂ, X. FILIP, F. MARTIN, G. SERBAN, I. KACSÓ

13. Y. He, H. Liu, W. Bian, Y. Liu, X. Liu, S. Ma, X. Zheng, Z. Du, K. Zhang, D. Ouyang, Pharmaceutics, 2019, 11, 442; doi:10.3390/pharmaceutics11090442

14. A. Celebioglu, T. Uyar, Food Chem., 2020, 317, 126397; doi:10.1016/j.foodchem. $2020.126397 \mathrm{R}$

15. U. Kannamangalam Vijayan, N. Nitin Shah, A. Bhimrao Muley, R. S. Singhal, J. Food Eng., 2021, 292, 110258; doi:10.1016/j.jfoodeng.2020.110258 R

16. M. Mohammadian, M. Moghadam, M. Salami, Z. Emam-Djomeh, F. Alavi, S. Momen, A. A. Moosavi-Movahedi, J. Drug Deliv. Sci. Technol., 2020, 56, 101531; doi:10.1016/j.jddst.2020.101531 R

17. A. M. Chuah, B. Jacob, Z. Jie, S. Ramesh, S. Mandal, J. K. Puthan, P. Deshpande, V. V. Vaidyanathan, R. W. Gelling, G. Patel, T. Das, S. Shreeram, Food Chem., 2014, 156, 227-233

18. A. R. Madureira, C. I. Pereira, A. M. P. Gomes, M. E. Pintado, F. X. Malcata, Food Res. Int., 2007, 40, 1197-1211

19. R. A. McGregor, S. D. Poppitt, Chapter 19 - Milk Proteins and Human Health, In Milk proteins: from expression to food, 2 nd ed., H. Singh, M. Boland, A. Thompson Eds., Academic Press, 2014, pp. 541-555

20. G. Kontopidis, C. Holt, L. Sawye, J. Dairy Sci., 2004, 87, 785-796

21. H. C. Liu, W. L. Chen, S. J. T. Mao, J. Dairy Sci., 2007, 90, 547-555

22. Y. Pan, Q.-T. Xie, J. Zhu, X.-M. Lia, R. Menga, B. Zhanga, H.-Q. Chena, Z.-Y. Jin, Food Chem., 2019, 287, 76-84

23. R. A. Awad, Z. M. R. Hassan, A. F. Farrag, M. M. El-Sayed, T. N. Soliman, IJFANS, 2015, 4(3), 125-131

24. W. Liu, X. D. Chen, Z. Cheng, C. Selomulya, J. Food Eng., 2016, 169, 189-195

25. G. K. Jayaprakashaa, K. N. Chidambara Murthya, B. S. Patil, Eur. J. Pharmacol., 2016, 789, 291-300.

26. M. Li, Y. Ma, J. Cui, LWT - Food Science and Technology, 2014, 59(1), 1-10

27. A. H. Sneharani, J. V. Karakkat, S. A. Singh, A. G. Appu Rao, J. Agric. Food Chem., 2010, 58, 11130-11139

28. M. Li, Y. Ma, M. O. Ngadi, Food Chem., 2013, 141, 1504-1511

29. C. D. Kanakis, P. A. Tarantilis, M. G. Polissiou, H. A. Tajmir-Riahi, J. Biomol. Struct. Dyn., 2013, 31(12), 1455-1466

30. M. I. Landin Neves, S. Desobrybanon, I. T. Perrone, S. Desobry, J. Petit, Powder Technol., 2019, 345, 601-607

31. M. Mohammadian, M. Salami, F. Alavi, S. Momen, Z. Emam-Djomeh, A. A. Moosavi-Movahedi, Food Biophys., 2019, 14, 425-436

32. C. Siregar, S. Martono, A. Rohman, J. Appl. Pharm. Sci., 2018, 8(08), 151-156

33. S. M. Beck, K. Knoerzer, J. Arcot, J. Food Eng., 2017, 214, 166-174

34. R. Arunkumar, C. J. Drummond, T. L. Greaves, Front. Chem., 2019, 7, 74; doi: 10.3389/fchem.2019.00074

35. A. Ciorîță, M. Suciu, S. Macavei, I. Kacso, I. Lung, M. L. Soran, M. Parvu, Molecules, 2020, 25(4), 819; doi:10.3390/molecules25040819

36. R. M. Levytskyy, Y. Z. Filyak, R. S. Stoika, Exp. Oncol., 2004, 26, 217-220

37. J. Li, Y. Wang, C. Yang, P. Wang, D. K. Oelschlager, Y. Zheng, D.-A. Tian, W. E. Grizzle, D. J. Buchsbaum, M. Wan, Mol. Pharmacol., 2009, 76, 81-90

38. S. Li, C. Fang, J. Zhang, B. Liu, Z. Wei, X. Fan, Z. Sui, Q. Tan, Nanomedicine: NBM, 2016, 12(6), 1567-1579 